\title{
Културне лиге - претече јавних библиотека у Србији
}

\section{Cultural Leagues - Forerunners of Public Libraries in Serbia}

\section{Тамара Малешев / Tamara Malešev ${ }^{1}$, Ирена Зечевић / Irena Zečević ${ }^{2}$, Оливера Топалов / Olivera Topalov $^{3}$}

\author{
' Библиотека Матице српске, Нови Сад, Србија / Matica Srpska Library, Novi Sad, Serbia \\ tamara.tamarica.m@gmail.com \\ ${ }^{2}$ Библиотека Матице српске, Нови Сад, Србија / Matica Srpska Library, Novi Sad, Serbia \\ irena.zecevic.bp@gmail.com \\ ${ }^{3}$ Градска библиотека, Нови Сад, Србија / Public Library, Novi Sad, Serbia \\ oliveratopalov@yahoo.com
}

\section{Informacije o članku / Article Info}

Primljen / Received 17. 9. 2020.

Prihvaćen / Accepted 20. 10. 2020.

Dostupan online / Available online: 15. 12. 2020.

\section{Кључне речи / Keywords}

Културне лиге, просвећивање, Србија, јавне библиотеке, читалишта

Cultural leagues, education, Serbia, public libraries, reading rooms

\begin{abstract}
Сажетак / Abstract
Оснивање културних друштава и институција широм Србије након Балканских ратова, било је један од приоритета Краљевине Србије. Осим Културне лиге, деловале су и српске земљорадничке задруге, радничка и партијска удружења, обједињени у важној мисији - образовању, просвећивању и културном уздизању свог народа. Ауторке рада настоје да прате историјски развој Културне лиге, чијим развојем и деловањем су се створили услови за настанак јавних библиотека у Србији.

The establishment of cultural societies and institutions throughout Serbia after the Balkan wars were one of the priorities of the Kingdom of Serbia. In addition to the Cultural League, there were also Serbian agricultural cooperatives, workers' and party associations, united in an important mission - education, enlightenment and cultural uplifting of their people. The authors of the paper try to follow the historical development of the Cultural League, whose development and activities have created the conditions for the emergence of public libraries in Serbia.
\end{abstract}

\section{Увод}

Од настанка света није било значајнијег изума од хартије и пера. Када је човек нашао начин да записује и преноси сазнања и знања, даље је све било неминовно надограђивање, развијање и усавршавање ка данашњем времену. Описмењавање и образовање су, од најранијих времена, постали један од најважнијих задатака и развијених и оних мање развијених друштава, а све у тежњи за бољим условима свеопштег живљења. Ако се сложимо да је појединац, личност, индивидуа, као нуклеус друштва, синоним за почетни импулс и снагу на путу развоја, онда она, у спрези са институцијама друштва и системом, мора дати пожељне резултате.

Говорећи о српском друштву, где је потлачени положај народа кроз историју био чест, улога појединца била је посебно наглашена. Имућни појединци који су били у прилици да се школују у иностранству, свештена лица, студенти, надарени млади људи, интелектуалци визионари и патриоте, међу првима су увидели значај

\section{Introduction}

Since the creation of the world, there has been no more significant invention than paper and quill. When man found a way to write down and transmit discoveries and knowledge, then everything was, inevitably, upgrading, developing and improving to to the present time. Literacy and education have, since the earliest times, become one of the most important tasks of both developed and less developed societies, all in the pursuit of better conditions for universal living. If we agree that the someone, person, individual, as the nucleus of society, is a synonym for the initial impulse and strength on the path of development, then, in conjunction with the institutions of society and the system, it must give the desired results.

Speaking of Serbian society, where the oppressed position of the people has been common throughout history, the role of the individual was especially emphasized. Wealthy individuals who had the opportunity to study abroad, clergy, students, talented young people, visionary intellectuals and patri- 
писане речи и ширења знања за даљи напредак Србије. Од стицања самосталности Кнежевине и Краљевине Србије (1830-1878) до краја Првог светског рата услови за оснивање школа и образовање наставног кадра били су више него скромни, али временом опште друштвене прилике су омогућавале улагање у образовање. Скупљајући књиге, часописе, приручнике и уџбенике које су сами користили, полако су формирали своје кућне библиотеке.

\section{Осврт на културно-историјска дешавања}

Историјске прилике на Балкану и у Србији су биле сложене, а у временима да ли под турском, хабзбуршком и аустроугарском влашћу, култура и образовање су били међу првима на удару, у културу и образовање није довољно улагано. Знало се да, ако се буде гушио образовни напредак и развој просвете, ако се буде урушавао школски систем, доћи ће у питање очување националног идентитета и материјалне и духовне баштине. Већи део становништва (90\%) у Сpбији у 19. веку бавио се земљорадњом и сточарством, удео градског становништва је варирао од 11 до 14\%, што јасно указује и на проценат неписмених, али и на недовољан број писмених, тј. кадра који би могао да описмењава и образује. Најзначајнији догађај у таквим околностима за српски народ била су три највиша царска акта, хатишерифи, $(1829,1830,1833)$ којима је Кнежевини Србији била гарантована: слобода вероисповести, оснивања школа, болница, штампарија, самостални судски органи, право на слободу кретања и бављење трговином. Од велике важности за државно уређење било је и доношење Сретењског устава (1835), којим је забрањен кулук, прокламована једнакости свих грађана пред судом и загарантована слобода вероисповести, чиме су се стекли повољни услови за даљи напредак и у области школства и просвете. Јован Стерија Поповић је сачинио "Устројеније јавног училиштног наставленија" (1844) које предвиђа оснивање основних, трговачких школа, гимназија и лицеја. Следећи значајан документ је “Закон о обавезном основном школовању” (1882) који предвиђа да држава финансира, организује и врши надзор над просветним системом у Србији.

\section{Културне лиге}

Иницијативом групе интелектуалаца, чланова српске културне елите, а по угледу на неке европске градове у којима су већ заживела таква ots, were among the first to see the importance of the written word and the spread of knowledge for the further progress of Serbia. From the independence of the Principality and the Kingdom of Serbia (1830-1878) until the end of the First World War, the conditions for the establishment of schools and the education of teachers were more than modest, but over time the general social circumstances enabled investment in education. By collecting books, journals, manuals, and textbooks that they used themselves, they have slowly formed their home libraries.

\section{A review of cultural and historical events}

The historical situation in the Balkans and in Serbia was complex, and in the times under Turkish, Habsburg or Austro-Hungarian rule, culture and education were among the first on the line, not enough was invested in culture and education. It was known that if educational progress and the development of education is stifling, if the school system collapses, the preservation of national identity and material and spiritual heritage would come in question. Most of the population $(90 \%)$ in Serbia in the $19^{\text {th }}$ century was working in agriculture and animal husbandry, the share of urban population varied from 11 to $14 \%$, which clearly indicate the percentage of illiterate, but also the insufficient number of literate, i.e. staff that could literate and educate. The most significant event, in such circumstances, for the Serbian people were the three highest imperial acts, hatt-i sharifs $(1829,1830,1833)$ which guaranteed the Principality of Serbia: freedom of religion, establishment of schools, hospitals, printing houses, independent judicial authorities, the right to freedom of movement and trading. Of great importance for the state system was the adoption of the Sretenje Constitution (1835), which banned corvée (statute labour), proclaimed the equality of all citizens before the court and guaranteed freedom of religion, which provided favorable conditions for further progress in the field of education. Jovan Sterija Popović composed "Ustrojenije javnog učilištnog nastavlenija" (Organization of public school education) (1844) which foresees the establishment of primary and trade schools, gymnasiums and lyceums. The next important document is "Zakon o obaveznom osnovnom školovanju" (the Law on Compulsory Primary Education) (1882), which provides that the state finances, organizes and supervises the education system in Serbia. 
или слична удружења и покрети, историјски извори бележе настанак Културне лиге у Србији током 1908. године. У најширем смислу речи, то је био покрет за културни препород земље. Носиоци “културног кода" у то време били су универзитетски професори, првенствено са Београдског универзитета, који су, као умни људи оног времена, осим свог основног позива на факултетима, сагледали неопходност ширења знања и образовања међу широким народним масама. Своју замисао прокламовали су низом културно-просветних активности. Један од челних људи овог покрета био је тадашњи ректор београдског универзитета Сава Урошевић ${ }^{1}$ који je, говорећи о значају просвећивања народа, истакао да су темељи једне напредне и устројене државе “висока просвећеност, висока култура, јака морална снага и опште благостање једног народа". ${ }^{2}$ Руководећи се овим начелима, покрет Културна лига имао је вишеструку улогу. Једна од важних активности била је обезбеђивање и пружање материјалне помоћи сиромашним ђацима и студентима, који су, потпомогнути финансијски, били у могућности да наставе своје школовање. У ту сврху је Културна лига формирала и свој фонд (1910. године), а први прилог је дао краљ Петар I Карађорђевић. Новац из фонда служио је за помоћ у раду локалних одбора Лиге, а подразумевао је, осим финансијске помоћи приликом школовања и набавке књига, и обезбеђивање одеће и обуће за угрожено становништво. Од велике важности је и податак да се покрет Културна лига залагао за школовање тзв. “женске омладине”, што је представљало прави изазов традиционалној друштвеној улози жена̂ и свести за потребом школовања женске деце у патријархалном окружењу. Важно је истаћи да су, поред покрета Културне лиге, значајну улогу у подизању просвете и културе међу народом имали и Друштво за народно просвећивање и школску хигијену, Коло српских сестара, Друштво студената природњака, Друштво за чување народног здравља и др.

Културно напредовање кроз описмењавање народа, стварање интелектуалног подмлатка, ширење писане речи и у градским и сеоским срединама, оснивање библиотека и земљорадничких

Сава Урошевић (Врмџа, Сокобања, 13. јануар 1863. - Београд, 14. септембар 1930) српски минеролог, ректор Универзитета у Београду, члан Српске академије наука

2 Културна лига: говор Саве Урошевића, ректора универзитета, на Конференцијама за организовање Културне лиге у моравском округу, 3-17.

\section{Cultural Leagues}

At the initiative of a group of intellectuals, members of the Serbian cultural elite, by following the example of some European cities in which such or similar associations and movements have already taken root, historical sources record the creation of the Cultural League in Serbia during 1908. In the broadest sense of the word, it was a movement for the cultural revival of the country. The bearers of the "cultural code" at that time were university professors, primarily from the University of Belgrade, who, as intellectual people of that time, in addition to their basic vocation at faculties, saw the need to spread knowledge and education among the masses. They proclaimed their idea through a series of cultural and educational activities. One of the leading people of this movement was the then - rector of the University of Belgrade Sava Urošević, ${ }^{1}$ who has, by speaking about the importance of education of people, pointed out that the foundations of an advanced and organized state are "high education, high culture, strong moral strength and general well-being of one nation". ${ }^{2}$ Guided by these principles, the Cultural League movement had a multiple role. One of the important activities was to ensure and provide material assistance to poor pupils and students, who were supported financially and were able to continue their education. For this purpose, the Cultural League formed its own fund (1910), and the first contribution was made by King Petar I Karađorđević. The money from the fund was used to help the work of the local boards of the League, and it included, in addition to financial assistance during schooling and the purchase of books, also provision of clothes and shoes for the endangered population. Of great importance is the fact that the Cultural League movement advocated for the education of the so-called "Female youth", which posed a real challenge to the traditional social role of women and awareness of the need to educate female children in a patriarchal environment. It is important to point out that, in addition to the Cultural League movement, significant role in raising education and culture among the people also had Društvo za narodno prosvećivanje i školsku higijenu (Society for Public Education and School Hygiene), Kolo srpskih sestara (Circle of Serbian Sisters), Društvo

\footnotetext{
Sava Urošević (Vrmdža, Sokobanja, 13 January 1863 - Belgrade, 14 September 1930) Serbian mineralogist, rector of the University of Belgrade, member of the Serbian Academy of Sciences

2 Cultural League: speech by Sava Urošević, Rector of the University at the Conferences for Organizing the Cultural League in the Moravian District. 3-17.
} 
задруга, били су такође важни задаци челника Културне лиге. Замисао “лигаша” је била и организовање тзв. "вечерњих састанака" у школама или библиотекама, у којима би се кроз дружење, седељке, уз пригодне разговоре организовало читање књига. Чланови Културних лига, професори, наставници, културни радници, позивани су да држе предавања и у другим друштвима на разне теме. Садржаји састанака били су разноврсни, од читања лепе књижевности, преко дискусија о актуелним проблемима становништва, еманципацији жена, здравственим темама, до певања и свирања недељом. Значи, обухватали су све области друштвеног живота осим политичких дебата.

Надлежности Одбора и пододбора Културних лига, као и обавеза подношења извештаја о раду, биле су дефинисане Статутом Културне лиге, који је настао 1909. године, годину дана по њиховом оснивању. Радом Културних лига руководила је Управа централног одбора преко одбора у срезовима и окрузима са којима је одржавала везе, шаљући упутства и програме за почетни рад, и помагала сваку новоотворену библиотеку између осталог тако што се обраћала разним установама и појединцима за бесплатно уступање књига. Извештаји о раду бележе дародавце, државне установе: Српска краљевска академија наука, Управа друштва Светог Саве, Матица српска, Професорски савет Богословије из Београда, Српски књижевни гласник, Министарство просвете, које су помажући Лигу уткали себе у културно-историјски препород нације. Срески и окружни одбори били су у обавези да Централном одбору достављају програм рада за следећу годину. Према извештајима које су подносили председници сеоских одбора, а подразумевали су исцрпне и прецизне податке о свим активностима, покрет Културна лига свој највећи успех је постигао у прве три године постојања (1908-1911) када је имао снажан замајац у оснивању књижница, читаоница за народ, сеоских библиотека, разних друштава. Председници су, свако из свог окружења, извештај слали Главном одбору Лиге, статистичке податке колико има корисника у библиотеци, бројчано стање књига и часописа, водила се евиденција о поклонима за библиотеку и њеним дародавцима, о интересовањима и укусима читалачке публике и др. Заједнички “именитељ” у свим извештајима је био: почетак рада читаоница, формирање библиотека, од којих је део библиотека у градским срединама био смештен у гимназијским studenata prirodnjaka (Society of Natural Science Students), Društvo za čuvanje narodnog zdravlja (Society for the Preservation of Public Health), etc. Cultural progress through the literacy of the people, the creation of intellectual youth, the spread of the written word in urban and rural areas, the establishment of libraries and agricultural cooperatives were also important tasks of the leaders of the Cultural League. The idea of the "league people" was to organize the so-called "evening meetings" in schools or libraries, in which through get-togethers, sittings, with appropriate conversations, book readings would be organized. Members of Cultural Leagues, professors, teachers, cultural workers, were invited to give lectures in other societies on various topics. The contents of the meetings were various, from reading fiction, discussing current problems of the population, emancipation of women, health topics, to singing and music playing on Sundays. Meaning, they covered all areas of social life except political debates.

The competencies of the Boards and subcommittees of the Cultural Leagues, as well as the obligation to submit work reports, were defined by the Statute of the Cultural League, which was created in 1909, one year after their establishment. The work of the Cultural Leagues was managed by the Management of the Central Board through the boards in the counties and districts with which they maintained contacts by sending instructions and programs for initial work, and assisting each newly opened library, among other things, by contacting various institutions and individuals for granting the books free of charge. Reports on the work record donors, state institutions: Srpska kraljevska akademija nau$k a$ (Serbian Royal Academy of Sciences), Uprava društva Svetog Save (Administration of the Society of St. Sava), Matica srpska, Profesorski savet Bogoslovije iz Beograda (Professorial Council of the Theological Seminary from Belgrade), Srpski književni glasnik (Serbian Literary Herald), Ministarstvo prosvete (Ministry of Education), which have by helping the League weaved themselves into the cultural-historical rebirth of the nation. The district boards were obliged to submit the work program for the next year to the Central Board. According to the reports submitted by the presidents of the village committees, which included exhaustive and precise data on all activities, the Cultural League movement achieved its greatest success in the first three years of its existence (1908-1911) when it had a strong impetus for establishing libraries, reading rooms for the people, village libraries, 
зградама, затим попуњавање њихових фондова чију основу су чиниле књиге добијене поклоном Управе Културне лиге из Београда, поклони институција или појединаца. Под њеним покровитељством биле су и трговачке школе, месна позоришта, певачка друштва, амбуланте и др. Такође су документовали велику заинтересованост становништва за читање, што је био важан моменат за подизање националне свести. Извештаји послати Министарству просвете и црквених послова бележе информацију да је током првих неколико година од почетка формирања и деловања Културних лига било основано 200 библиотека у Србији, од којих је 150 било у сеоским срединама.

По историјским подацима, почетак рада и деловања Културне лиге на овим просторима најпре је започео у Моравском округу, организовањем образовних одбора, па је тако крајем јула 1909. године најпре настао у Свилајнцу. За председника Одбора је био изабран образован и угледан човек заједнице, писац, политичар и министар просвете у Краљевини Србији, Лука Лазаревић, ${ }^{3}$ који је у то време обављао функцију директора ондашње приватне гимназије. Чињеница да је Свилајнац имао Читаоницу омладине ресавске, ${ }^{4}$ која је касније прерасла у Библиотеку, била је за “лигаше" олакшавајућа околност, јер су учени људи тог краја “имали слуха" за сарадњу, а то је био важан почетни импулс, помоћ и подстрек за даљи развој.

Лига за кратко време бележи велики замах и омасовљавање, по устаљеном протоколу, формирањем месних и среских одбора, настављајући свој просветитељски пут и у осталим срезовима у земљи реализујући значајан број васпитно-образовних активности. Образовни одбори су, свако у свом месту, уз првобитну идеју, описмењавање становништва, поспешили рад постојећих и оснивање нових друштава и удружења. Добар одзив у народу су имале новоформиране певачке, стрељачке, као и позоришне дружине, гимнастичка друштва, затим разни курсеви за домаћице, отварање школа за неписмене девојке и др. У његовој надлежности су такође били: хигијена, сузбијање пијанства и неморала, оснивање

\footnotetext{
Лука Лазаревић (1857-1936) министар просвете и црквених дела у првој и другој влади Димитрија Цинцар-Марковића

4 Ресавска библиотека је основана 23. августа у Свилајнцу, као Читаоница омладине ресавске. Променила је име 1905. године у Библиотека омладине ресавске, а 1931. године добила свој данашњи назив - Ресавска библиотека.
}

various societies. The presidents, each from their environment, sent a report to the Main Board of the League, statistical data on the number of users in the library, the number of books and journals, records on gifts for the library and its donors, interests and tastes of readers, etc. The common "denominator" in all reports was: the beginning of the work of reading rooms, the establishment of libraries, some of which were located in gymnasium buildings in urban areas, then the collection building based on books obtained as a gift from the Belgrade Cultural League, gifts of institutions or individuals. Under its patronage were also trade schools, local theaters, singing societies, dispensaries, etc. They also documented the great interest of the population in reading, which was an important moment for raising national awareness. Reports sent to the Ministry of Education and Church Affairs record information that during the first few years since the creation and operation of the Cultural Leagues, 200 libraries were established in Serbia, of which 150 were in rural areas.

According to historical data, the beginning of the work and activities of the Cultural League in this area first began in the Moravian district, by organizing educational boards, and so, at the end of July 1909, first was established in Svilajnac. An educated and respectable man of the community, writer, politician and Minister of Education in the Kingdom of Serbia, Luka Lazarević, was elected chairman of the board, ${ }^{3}$ who at that time was the director of the then private high gymnasium. The fact that Svilajnac had Čitaonica omladine resavske ${ }^{4}$ (Reading room of the Youth of Resava), which later evolved into the Library, was a mitigating circumstance for the "league people", because the educated people of that area "had an understanding" for cooperation, and that was an important initial impulse, help and encouragement for further development.

In a short time, the League recorded a great momentum and popularization, according to the established protocol, with the establishing of local and district boards, continuing its educational path in other districts in the country, realizing a significant number of educational activities. The education boards, each in its own place, with the original idea, literacy of the

\footnotetext{
3 Luka Lazarević (1857-1936) Minister of Education and Church Affairs in the First and Second Government of Dimitrij Cincar-Marković

${ }^{4}$ Resavska biblioteka (Resava Library) was founded on August 23 in Svilajnac, as Čitaonica omladine resavske (Reading Room of the Resava Youth). In 1905, it changed its name to Biblioteka omladine resavske (Youth Library of Resava), and in 1931 it got its current name - Resavska biblioteka (Resava Library).
} 
фондова за потребе финансијске помоћи, као и остала друштвена питања корисна за заједницу. У ширењу покрета Културне лиге по окрузима и срезовима у земљи велику улогу је одиграла Главна управа Београдске лиге, која је изузетним напорима и ангажовањем, препознајући кључни моменат културно-образовног процеса нације, настојала да новоформираним библиотекама као почетни фонд пошаље известан број књига. У селима се, иницијативом Лига, формирају школе у које се допремају књиге послате из Управе Културне лиге. Одабрани образовани чланови Лиге су, свако у свом срезу, просветитељску мисију обављали подучавајући неписмено сеоско становништво. Бележе се и бројне активности, које су се у виду предавања, отварања школа, вечерњих школа за неписмене младиће такође одвијале у сеоским срединама, те се талас покрета Културна лига ширио великом брзином, срез по срез (белићки, ресавски, деспотовачки...), место по место (Свилајнац, Јагодина, Ћуприја, Крушевац, Врање...), као и у мањим местима и селима, захватајући све крајеве земље.

Развојни пут био је веома тежак. Уз скромна финансијска средства, локали књижница добијали су се бесплатно, у неким већ постојећим државним зградама. Чест пример је био да су књижничари радили без икакве надокнаде. Учени и виђенији људи, универзитетски професори, судије, лекари, учитељи, адвокати, директори школа и гимназија постали су челни људи лига свако у свом крају и својим ауторитетом и ангажованошћу знатно допринели њиховом развоју. Међу бројним интелектуалцима, запажену улогу на тадашњој културној сцени Србије у време настанка и развоја лига имао је и Јован Н. Томић, ${ }^{5}$ који је обављао улогу библиотекара у Крушевачкој библиотеци. Током свог стручног усавршавања једно време је живео у Француској и Италији од 1894. до 1896. године, студирајући библиотекарство, те су његова међународна искуства била добродошла где год је био радно ангажован, па је у његовој радној биографији забележено да је у периоду од 1903. до 1927. био и директор Народне библиотеке Србије.

Пратећи историјске токове библиотекарства на овим просторима, Владимир Ћоровић ${ }^{6}$ се пи-

Јован Томић (Нова Варош, 9. мај 1869. - Београд, 22. јул 1932) српски историчар, академик и бивши директор Народне библиотеке Србије од 1903. до 1927.

Др Владимир Ћоровић (Мостар, 27. октобар 1885. - Еласона, 12. април 1941) српски историчар и редовни члан Српске краљевске академије population, encouraged the work of existing and the establishment of new societies and associations. A good response among the people had newly formed singing, firing, as well as theater companies, gymnastics societies, then various courses for housewives, opening of schools for illiterate girls, etc. In its responsibilities were also included: hygiene, inhibition of drunkenness and immorality, establishing funds for financial assistance, as well as other social issues useful to the community.

In the expansion of the Cultural League movement in the districts and counties in the country, a great role was played by the General administration of the Belgrade League, which, with exceptional efforts and engagement, recognizing the key moment of the cultural and educational process of the nation, tried to send a number of books to the newly formed libraries as a starting fund. In the villages, at the initiative of the League, schools are being formed to which books sent from the Cultural League Administration are delivered. Selected educated members of the League, each in their own district, performed an educational mission by teaching the illiterate rural population. Numerous activities are also recorded, which in the form of lectures, opening of schools, evening schools for illiterate young men also took place in rural areas, and the wave of the Cultural League movement spreaded with great speed, district by district (Belički, Resavski, Despotovački...), place by place (Svilajnac, Jagodina, Ćuprija, Kruševac, Vranje...) as well as smaller places and villages, covering all parts of the country.

The development path was very difficult. With modest financial resources, library premises were provided free of charge, in some already existing state buildings. A common example was that librarians worked without any compensation. Scholars and prominent people, university professors, judges, doctors, teachers, lawyers, school and gimnasyum principals have become the leading people of the Leagues, each in its own region, and with their authority and commitment have significantly contributed to their development. Among numerous intellectuals, a notable role on then cultural scene of Serbia, at the time of the formation and development of the League, had Jovan N. Tomić, ${ }^{5}$ who performed the role of librarian in the Kruševac library. During his professional training, he lived for

\footnotetext{
Jovan Tomić (Nova Varoš, May 9, 1869 - Belgrade, July 22, 1932) was a Serbian historian, academician and former director of the $\mathrm{Na}$ tional Library of Serbia from 1903 to 1927.
} 
шући “О градским књижницама у Србији” осврнуо на значајан допринос Лига. По његовим речима: "Културна лига, основана у крилу Универзитета, има обилан задатак ширења целокупне културе у најдубље слојеве, и према том задатку, оснива књижнице, ствара школе, организује културна друштва, одржава по многим крајевима Србије јавна популарна предавања, и ради уопште на подизању културних односа у земљи." Разматрајући развојни пут библиотекарства у Србији, више примера из историје нам је потврђивало да су управо мале, скромне, личне библиотеке прерастале у читалишта, а временом и у школске и локалне библиотеке. Поред прве и најстарије Српске читаонице у Иригу (1842), која је уједно представљала и најстарије грађанско читалиште у Срба, пример вредан пажње је и формирање библиотеке Православне богословије "Светих Кирила и Методија" у Призрену $(1871),{ }^{7}$ која је увек била отворена и као читалиште за све који су желели да је користе. Њен почетни фонд чиниле су књиге сина Симе Андрејевића Игуманова, ${ }^{8}$ трговца из Призрена, који je, после смрти, целокупан библиотечки фонд даривао Библиотеци призренске богословије.

\section{Читалишта}

У настојању да се што боље сагледа историјски ток развоја културних лига на овим просторима, неопходно је најпре осврнути се на читалишта, која су настала у Војводини, а затим заживела и у осталим деловима земље. Историјски подаци говоре да су читаонице или читалишта институције које оснивају приватно удружени грађани, финансирају се од прилога, уписнине, чланарине, претплата или донација. Набавка грађе била je усредсређена на периодичне публикације. У почетку, књиге се нису набављале, већ само дневне новине и часописи, јер су они доносили актуелне информације о грађанима и приликама у којима су живели. Слободан приступ штампаној грађи, културно-просветна активност, међусобна сарадња и издавачка делатност још су неке од карактеристика деловања поменутих читаоница. Тренд оснивања читалишта започет је у Европи и Америци. Иако су имали различите називе: чи-

\footnotetext{
Призренска богословија - Богословија Светог Кирила и Методија задужбина је Симе Андрејевића Игуманова. Почела је са радом 1871. године и у почетку се звала Богословскоучитељска школа, намењена српским учитељима и свештеницима из Старе Србије.

8 Сима Андрејевић-Игуманов (Призрен, 30. јануар 1804. - Призрен, 24. фебруар 1882) српски трговац, хуманиста и црквено-просветни добротвор. Био је један од првих задужбинара у области школства и народне просвете.
}

a one period in France and Italy from 1894 to 1896, studying librarianship, and his international experiences were welcomed wherever he was employed, so in his work biography it is noted that in the period from 1903 until 1927, he was also the director of the National Library of Serbia.

Following the historical trends of librarianship in this area, Vladimir Ćorović ${ }^{6}$ by writing "O gradskim knjižnicama u Srbiji" (About city libraries in Serbia) reflected on the significant contribution of the League. According to him: "The Cultural League, founded within the University, has a rich task of spreading the entire culture to the deepest levels, and according to that task, it establishes libraries, creates schools, organizes cultural societies, holds popular public lectures in many parts of Serbia, and works in general on raising cultural relations in the country."

Considering the development path of librarianship in Serbia, several examples from history confirmed to us that small, modest, personal libraries have grown into reading rooms, and over time into school and local libraries. In addition to the first and oldest Serbian reading room in Irig (1842), which was also the oldest civic reading room among Serbs, noteworthy example is the establishing of the library of Pravoslavna bogoslovija "Svetih Kirila i Metodija" (Orthodox Theological Seminary of Holy Cyril and Methodius) in Prizren (1871), ${ }^{7}$ which was always open as a reading room for all who wanted to use it. Its initial fund consisted of books by the son Simo Andrejević Igumanov, ${ }^{8}$ a merchant from Prizren, who, after his death, donated the entire library fund to the Library of the Prizren Theological Seminary.

\section{Reading rooms}

In an effort to better understand the historical course of development of Cultural Leagues in this area, it is necessary to first look at the reading rooms, which originated in Vojvodina, and then came to life in other parts of the country. Historical data show that reading rooms are institutions founded by privately associated citizens, financed by contributions,

\footnotetext{
6 Dr. Vladimir Ćorović (Mostar, October 27, 1885 - Elassona, April $12,1941)$ Serbian historian and full member of the Serbian Royal Academy.

7 Prizren Theological Seminary - The Theological Seminary of Holy Cyril and Methodius is the endowment of Sima Andrejevic Igumanov. It started working in 1871 and was initially called the Theological-Teachers School, intended for Serbian teachers and priests from Old Serbia.

8 Sima Andrejević-Igumanov (Prizren, January 30, 1804 - Prizren, February 24, 1882) was a Serbian merchant, humanist and church-educational benefactor. He was one of the first donors of endowments in the field of schooling and public education.
} 
талачки салони, касине, литерални клубови или књижевна друштва, циљеви и задаци су били исти: задовољавање потреба за читањем, знањем и информацијама. "Могли су да читају новине, часописе и друге публикације набављене према сопственим потребама, да се информишу, да се образују на курсевима организованим за чланове, да се друже и међусобно обавештавају о питањима важним за њихов рад и послове и да се забављају." (Стаматовић 2011, 260)

Према расположивим подацима, а позивајући се на истраживачке радове Десанке Стаматовић и Карле Селихар, читалишта у Војводини се оснивају нешто раније него у другим деловима Сpбије. "У првом периоду (1842-1849), основано је пет читаоница на територији тадашње Војводине: у Иригу (1842), Сомбору (1845), Кикинди (1845), Новом Саду (1845), Мокрину (1847) и Шиду (1849). Делатност ових читаоница прекинула је мађарска револуција 1848/49. године, након чега је наступио период стагнације на целокупној територији Аустроугарске монархије, за време Баховог апсолутизма и гушења свих грађанских и националних слобода." (Селихар $2017,28)$ Од 1846 . године оснивају се читаонице у Београду, Крагујевцу, Смедереву, Ужицу, Неготину, Шапцу, Пожаревцу... Године 1879. почињу са радом и у Нишу, Врању и Лесковцу. На територији Војводине користи се назив читаоница, а у Србији је назив читалиште коришћен до 1867. године, када је и Београдско читалиште ${ }^{9}$ променило назив у Београдска читаоница.

У жељи да се српска духовност очува под туђинском влашћу, у периоду XIX века проналажени су разни начини да књиге и часописи буду доступни што већем броју људи и да буду читани. Одржање националног идентитета изнедрило је читалишта која нису била само места за необавезна дружења већ и места за чување националног блага. Поменућемо и најстарију читаоницу у Војводини, Српску читаоницу у Иригу, коју су основали иришки Срби 1842. године. Њен циљ је био да, поред књига на страним језицима, купује и сваку српску књигу или новине које се појаве, нарочито књиге које је издавала Матица српска, како би се помогла српска књижевност. Постоји само један документ који потврђује да је Иришка библиотека и читаоница најстарија установа ове врсте Срба у Војводини. Реч је о

\footnotetext{
9 Читалиште београдско, Београдско читалиште, по оснивању названо “Српско читалиште у Београду” основано је 2. јануара 1846. и било је прва јавна читаоница и једна од најстаријих установа у Србији.
}

registration fees, membership fees, subscriptions or donations. Acquisition of materials was focused on periodical publications. In the beginning, books were not acquisitioned, but only daily newspapers and journals have been, because they brought up-todate information about citizens and the conditions they lived in. Free access to printed materials, cultural and educational activity, mutual cooperation and publishing activity are some of the characteristics of the mentioned reading rooms. The trend of establishing reading rooms has started in Europe and America. Although they had different names: reading saloons, casinos, literal clubs or literary societies, the goals and tasks were the same: meeting the needs for reading, knowledge and information. "They could read newspapers, journals and other publications acquisitioned according to their own needs, to get information, to get education in courses organized for members, to socialize and inform each other about issues important to their work and affairs, and to have fun." (Stamatović 2011, 260)

According to the available data, and referring to the research works of Desanka Stamatović and Karla Selihar, reading rooms in Vojvodina were established somewhat earlier than in other parts of Serbia. "In the first period (1842-1849), five reading rooms were established on the territory of the then Vojvodina: in Irig (1842), Sombor (1845), Kikinda (1845), Novi Sad (1845), Mokrin (1847) and Šid (1849). The activity of these reading rooms was interrupted by the Hungarian revolution in 1848/49, after which there was a period of stagnation in the entire territory of the Austro-Hungarian monarchy, during Bach's absolutism and the suppression of all civil and national freedoms." (Selihar 2017, 28) Since 1846, reading rooms have been established in Belgrade, Kragujevac, Smederevo, Užice, Negotin, Šabac, Požarevac... In 1879, they started working in Niš, Vranje and Leskovac. In the territory of Vojvodina, term citaonica (reading room) is used, and in Serbia, term citalište (reading room) was used until 1867, when Beogradsko citalište ${ }^{9}$ (Belgrade Reading Room) also changed its name to Beograds$k a$ čitaonica (Belgrade Reading Room).

In the desire to preserve Serbian spirituality under foreign rule, in the period of the 19th century, various ways were found to make books and journals accessible to as many people as possible and to be

\footnotetext{
Čitalište beogradsko, Beogradsko čitalište (Belgrade Reading Room), upon establishment called Srpsko čitalište u Beogradu (Serbian Reading Room in Belgrade) was founded on January 2, 1846 and was the first public reading room and one of the oldest institutions in Serbia.
} 
књизи Доситеја Обрадовића “Писма”, са малом посветом и драгоценим датумом 20. фебруар 1842. година. У њему, као и у свим другим читалиштима, одржавана су предавања, забаве, балови, позоришне представе... Нажалост, судбина овог читалишта као и многих других у земљи била је иста. Зграда је за време Другог светског рата уништена, а заједно са њом и целокупан библиотечки фонд. Али, после рата је обновљена и наставила је са својим активностима, да би изнедрила данас модерну библиотеку, Српску читаоницу у Иригу (Dotcom 2017).

Оснивање Српске читаонице у Новом Саду 1845. године омогућено је прикупљањем добровољних прилога на баловима (Којић 1996). Читаоницу схватају као бедем одбране свог језика, народности и свог идентитета. У њој желе да читају српске књиге и новине, и она постаје средиште културног живота Срба у Војводини. У крилу Српске читаонице основано је и Српско народно позориште, прво Српско певачко друштво (Читаоничко певачко друштво), Новосадско српско коло, Девојачко и омладинско коло... По избијању Првог светског рата, Аустроугарска уништава бројна архивска документа, чиме је учињена ненадокнадива штета по културну историју наших крајева. Ипак, и поред неповољних околности, на територији северно од Саве и Дунава настављен је просветни и живот културних установа. Крајем ратних сукоба обновљен je, у Краљевини Срба, Хрвата и Словенаца, рад библиотека и музеја. Једна од институција чији је траг у времену могуће пратити је Српска читаоница у Новом Саду. Данашњи истраживачи културних збивања бележе чињенице (верификоване архивалијама из Архива Војводине и Историјског архива града Новог Сада) да је на темељима Српске читаонице у Новом Саду настала једна од највећих јавних библиотека у Сpбији, Градска библиотека у Новом Саду.

И данас, у 21. веку и времену доминације дигиталних технологија, у Србији постоје удружења која се не одричу културне мисије. Једно од њих је и удружење "Адлигат"10 из Београда, које је настало из приватне библиотеке (1882) Михаила Лазића, православног свештеника, у чијем дому су боравили љубитељи писане речи, те су његова лична библиотека и амбијент служили као читалиште.

\footnotetext{
10 Удружење “Адлигат” је невладино, непрофитно удружење грађана, са седиштем у Београду, које се бави унапређењем српске културе, уметности и међународне сарадње.
}

read. The maintenance of national identity created reading rooms that were not only places for casual socializing but also places for preserving national treasures. We will also mention the oldest reading room in Vojvodina, the Serbian reading room in Irig, which was founded by Irig's Serbs in 1842. Its goal was to buy, in addition to books in foreign languages, every Serbian book or newspaper that appeared, especially books published by Matica srps$k a$, in order to help Serbian literature. There is only one document that confirms that Iriška biblioteka $i$ čitaonica (Irig's Library and Reading Room) is the oldest institution of this type of Serbs in Vojvodina. It is the book of Dositej Obradovic "Pisma" (Letters), with a small dedication and a precious date of February 20, 1842. In it, as in all other reading rooms, lectures, parties, balls, theater performances were held... Unfortunately, the fate of this reading room as well as many others in the country was the same. The building was destroyed during the Second World War, and together with it, the entire library fund. But, after the war, it was renovated and continued with its activities, in order to create a modern library today, Srpska čitaonica (Serbian Reading Room) in Irig. (Dotcom 2017)

The establishment of Srpska čitaonica (Serbian Reading Room) in Novi Sad in 1845 was made possible by collecting voluntary contributions at dances (Kojić 1996). They understand the reading room as a rampart for the defense of their language, nationality and identity. They want to read Serbian books and newspapers in it, and it becomes the center of the cultural life of Serbs in Vojvodina. Within the Srpska čitaonica (Serbian Reading Room) were also founded Srpsko narodno pozorište (Serbian National Theater), first Srpsko pevačko društvo (Čitaoničko pevačko društvo) (Serbian Singing Society (Reading Singing Society)), Novosadsko srpsko kolo (Serbian Circle of Novi Sad), Devojačko i omladinsko kolo (Girls' and Youth Circle)... After the outbreak of the First World War, Austria-Hungary destroyed numerous archival documents, which caused irreparable damage to the cultural history of our region.

However, despite the unfavorable circumstances, in the territory north of the Sava and the Danube, the educational and cultural life of the cultural institutions continued. At the end of the war, the work of libraries and museums in the Kingdom of Serbs, Croats and Slovenes was renewed. One of the institutions whose trace in time can be followed is Srpska čitaonica (Serbian Reading Room) in Novi Sad. Today's researchers of cultural events note the facts (verified by archives from the Archives of 


\section{Закључак}

Настале у бурним временима, у турбулентним друштвено-политичким приликама, Културне лиге су резултат залагања и деловања српске културне елите, првенствено универзитетских професора из Београда, који су, сагледавајући неопходност просвећивања и описмењавања српског народа, како у градовима, тако и у сеоским срединама, своју улогу јачања националне свести озбиљно схватили. Имајући на уму важност учешћа у том процесу, своју мисију су реализовали кроз низ програма и активности, у циљу образовања и културног препорода народа на овим просторима. У времену пред Први светски рат, у прве две деценије 20. века, Културне лиге су организационим капацитетима и осмишљеним друштвеним акцијама утицале на културну политику у Краљевини Србији. Организација Културне лиге у многим нашим местима знатно је утицала и на развој библиотечко-информационе делатности у нашој држави. Културна лига је била не само претеча, него и снажан замајац оснивању и почетним корацима јавних библиотека у Краљевини и Републици Србији.
Vojvodina and the Historical Archives of the City of Novi Sad) that one of the largest public libraries in Serbia, Gradska biblioteka (City Library) in Novi Sad, was established on the foundations of Srpska čitaonica (Serbian Reading Room) in Novi Sad.

Even today, in the 21 st century and the time of domination of digital technologies, there are associations in Serbia that don't renounce on cultural mission. One of them is the association "Adligat"10 from Belgrade, which originated from the private library (1882) of Mihailo Lazić, Orthodox priest, in whose home the fans of the written word stayed, and his personal library and ambiance served as a reading room.

\section{Conclusion}

Created in rough times, in turbulent socio-political circumstances, Cultural Leagues are the result of the efforts and actions of the Serbian cultural elite, primarily university professors from Belgrade, who have, considering the need to educate the Serbian people, both in cities and in rural areas, their role in strengthening national consciousness, took seriously. Bearing in mind the importance of participation in this process, they realized their mission through a series of programs and activities, in order of education and cultural revive of the people in this area. In the time before the First World War, in the first two decades of the 20th century, the Cultural Leagues, with their organizational capacities and designed social actions, have influenced the cultural policy in the Kingdom of Serbia. The organization of the Cultural League in many of our places has significantly influenced the development of library and information activities in our country. The Cultural League was not only a predecessor, but also a strong impetus for the establishment and initial steps of public libraries in the Kingdom and in the Republic of Serbia.

\footnotetext{
10 Association "Adligat" is a non-governmental, non-profit Association of Citizens, based in Belgrade, which deals with the promotion of Serbian culture, art and international cooperation
} 


\section{Библиографија}

- Вучковић, Жељко. 2003. Јавне библиотеке и јавно знање. Нови Сад: Библиотека Матице српске; Футура публикације.

- Драгосавац, Бранка. 2016. Јавне библиотеке у Србији: од 1901. до 1918. године. Панчево: Градска библиотека; Ниш: Народна библиотека “Стеван Сремац”; Неготин: Народна библиотека “Доситеј Новаковић”.

- Којић, Драган. 1996. "150 година Српске читаонице у Новом Саду" У Српска читаонииа Градска библиотека у Новом Саду: споменииа: 1845-1995, ур. Божидар Ковачек et all., 7-13. Нови Сад: Градска библиотека.

- Селихар, Карла. 2017. “Значај читаоничког покрета код Срба у Војводини од 1842. до 1918. за очување културног и националног идентитета" Рад представљен на: Библиотеке и идентитет, Панчево, Србија, 25. и 26. маја 2017.

- Српске новине. 1911. Рад Културне Лиге у 1910-1911. години, прештампано из Српских новина, Београд: Штампано у државној штампарији Краљевине Србије, 1911: 38-43.

- Стаматовић, Десанка. 2011. Читалишта у Србији у XIX веку. Панчево: Градска библиотека.

- Стокић, Симончић. (ур.) 2018. Библиотеке и идентитет. Панчево: Градска Библиотека; Нови Сад: Центар за културу и екологију Панарат; Филозофски факултет; Сомбор: Педагошки факултет.

- Ћоровић, Владимир. 1912. О градским къижсницама у Србији. Сарајево: Штампарија народа.

- Ђуровић, Арсен. 2004. Модернизаиија образовања у Краљвевини Србији 1905-1914. Београд: Историјски институт.

- Dotcom. 2017. "Obeležavanje 175 godina Prve Srpske čitaonice u Irigu" Dotcom Nepolitikin zabavnik, 15. 2. 2017. https://www.dotkomsite. com/price-iz-ravnice/obelezavanje-175-godinaprve-srpske-citaonice-u-irigu/. Datum pristupa 26. 10. 2020.

\section{Bibliography}

- Vučković, Željko. 2003. Javne biblioteke i javno znanje. Novi Sad: Biblioteka Matice srpske; Futura publikacije.

- Dragosavac, Branka. 2016. Javne biblioteke u Srbiji: od 1901. do 1918. godine. Pančevo: Gradska biblioteka; Niš: Narodna biblioteka "Stevan Sremac"; Negotin: Narodna biblioteka "Dositej Novaković".

- Kojić, Dragan. 1996. "150 godina Srpske čitaonice u Novom Sadu" In Srpska čitaonica Gradska biblioteka u Novom Sadu: spomenica: 1845-1995, ed. Božidar Kovaček et all., 7-13. Novi Sad: Gradska biblioteka.

- Selihar, Karla. 2017. "Značaj čitaoničkog pokreta kod Srba u Vojvodini od 1842. do 1918. za očuvanje kulturnog i nacionalnog identiteta" Paper presented at: Biblioteke i identitet, Pančevo, Srbija, May $25^{\text {th }}$ and $26^{\text {th }} 2017$.

- Srpske novine. 1911. Rad Kulturne Lige u 1910 1911. godini, preštampano iz Srpskih novina, Beograd: Štampano u državnoj štampariji Kraljevine Srbije, 1911: 38-43.

- Stamatović, Desanka. 2011. Čitališta u Srbiji u $X I X$ veku. Pančevo: Gradska biblioteka.

- Stokić, Simončić. (ed.) 2018. Biblioteke $i$ identitet. Pančevo: Gradska Biblioteka; Novi Sad: Centar za kulturu i ekologiju Panarat; Filozofski fakultet; Sombor: Pedagoški fakultet.

- Ćorović, Vladimir. 1912. O gradskim knjižnicama u Srbiji. Sarajevo: Štamparija naroda.

- Đurović, Arsen. 2004. Modernizacija obrazovanja u Kraljevini Srbiji 1905-1914. Beograd: Istorijski institut.

- Dotcom. 2017. "Obeležavanje 175 godina Prve Srpske čitaonice u Irigu" Dotcom Nepolitikin zabavnik, 15. 2. 2017. https://www.dotkomsite. com/price-iz-ravnice/obelezavanje-175-godinaprve-srpske-citaonice-u-irigu/. Accessed 26. 10. 2020. 